\title{
Piperazine-Substituted Chalcones: A New Class of MAO-B, AChE, and BACE-1 Inhibitors for the Treatment of Neurologic Al Disorders
}

\author{
Bijo Mathew ( $\sim$ bijovilaventgu@gmail.com ) \\ amrita school of pharmacy https://orcid.org/0000-0002-6658-4497 \\ Jong Min Min Oh \\ Suncheon Daehakgyo: Sunchon National University

\section{Sarah Al-Rashed} \\ King Saud University

\section{Gaber El-Saber Batiha} \\ Damanhour University

\section{Della Grace Thomas Parambi} \\ Al Jouf University: Al-Jouf University \\ Nicola Gambacorta \\ University of Cagliari: Universita degli Studi Di Cagliari \\ Orazio Nicolotti \\ University of Cagliari: Universita degli Studi Di Cagliari \\ Hoon Kim \\ Suncheon National University: Sunchon National University
}

\section{Research Article}

Keywords: Piperazine, Chalcone, Monoamine oxidase, Acetylcholinesterase

Posted Date: February 5th, 2021

DOI: https://doi.org/10.21203/rs.3.rs-158102/v1

License: () This work is licensed under a Creative Commons Attribution 4.0 International License. Read Full License

Version of Record: A version of this preprint was published at Environmental Science and Pollution Research on March 20th, 2021. See the published version at https://doi.org/10.1007/s11356-021-13320-y. 


\section{Abstract}

Eleven piperazine-containing 1,3-diphenylprop-2-en-1-one derivatives (PC1-PC11) were evaluated for their inhibitory activities against monoamine oxidases (MAOs), cholinesterases (ChEs), and $\beta$-site amyloid precursor protein cleaving enzyme 1 (BACE-1) with a view toward developing new treatments for neurological disorders. Compounds PC10 and PC11 remarkably inhibited MAO-B inhibition with $\mathrm{IC}_{50}$ values of 0.65 and $0.71 \mu \mathrm{M}$, respectively. Ten of the eleven compounds weakly inhibited AChE and BChE with $>50 \%$ of residual activities at $10 \mu \mathrm{M}$, although PC4 inhibited AChE by $56.6 \%\left(\mathrm{IC}_{50}=\right.$ $8.77 \mu \mathrm{M})$. Compound PC3 effectively inhibited BACE-1 ( $\left.\mathrm{IC}_{50}=6.72 \mu \mathrm{M}\right)$, and PC10 and PC11 moderately inhibited BACE-1 ( $\mathrm{IC}_{50}=14.9$ and $15.3 \mu \mathrm{M}$, respectively). Reversibility and kinetic studies showed that PC10 and PC11 were reversible and competitive inhibitors of MAO-B with $K_{i}$ values of $0.63 \pm 0.13$ and $0.53 \pm 0.068 \mu \mathrm{M}$, respectively. ADME predictions for lead compounds revealed that PC10 and PC11 have central nervous system (CNS) drug-likeness. Molecular docking simulations showed that fluorine atom and trifluoromethyl group on PC10 and PC11, respectively, interacted with the substrate cavity of the MAO-B active site. Our results suggested that PC10 and PC11 be considered potential candidates for the treatment of neurological disorders such as Alzheimer's disease and Parkinson's disease.

\section{Introduction}

Of the heterogeneous and complex neurodegenerative disorders (NDDs) that largely affect the elderly, Alzheimer's disease (AD) and Parkinson's disease (PD) are the most prevalent and their pathogenesis have been attributed to a variety of genomic, epigenomic, and environmental factors (Van Bulck et al. 2019). Mounting evidence indicates that drugs targeting a single pathway cannot adequately address the multifactorial pathophysiologies of NDDs (Geldenhuys et al. 2011). Oxidative stress, mitochondrial dysfunction, and imbalances in the levels of enzymes that control the metabolism of biogenic amines may promote NDD progression (Barnham et al. 2004, Lin and Beal. 2006). On the other hand, several molecular scaffolds have been designed to simultaneously target entities such as choline esterase (ChE), monoamine oxidases (MAOs), and $\beta$-site amyloid precursor protein cleaving enzyme 1 ( $\beta$-secretase, BACE- 1 ), to retard NDD progression (Zhang et al., 2019).

Piperazine is a heteromonocyclic, six-membered ring containing two secondary nitrogen atoms, and an azacycloalkane with a non-planar, flexible nature that can interact hydrophobically by and hydrogen bonding with target enzymes. Furthermore, piperazine is a privileged structure with acknowledged "drug-likeness" and balanced pharmacodynamic and pharmacokinetic properties (Rathi et al. 2016). Currently, more than 40 piperazines have been FDA-approved as antianginals, antidepressants, antiserotonergics, urologicals, anthelmintics, antineoplastic agents, nootropics, and tranquillizers (Brito et al. 2019). Furthermore, the substitution of one or both nitrogen atoms in the piperazine ring system with various structural motifs can result in significant MAO-A, MAO-B, and acetylcholinesterase (AChE) inhibitions (Pettersson et al. 2012; Kaya et al. 2017; Kumar et al. 2018; Özdemir et al. 2020; Sağlık et al. 2020; Jevtić et al. 2020; Modh et al. 2013; Sahin et al., 2018).

On the other hand, 1,3-diphenylprop-2-en-1-one is a chalcone that contains phenyl and heteroaryl groups separated by a rotatable three-carbon units. This linker is an a, $\beta$-unsaturated ketone with trans orientated olefinic linkage (Zhuang et al. 2017). More than $90 \%$ of the chalcones synthesized exhibit selective MAO-B inhibition (Guglielmi et al., 2020), and analogs of chalcones with furan, thiophene, indole, imidazole, or morpholine heterocyclic entities on the $\mathbf{A}$ ring of $a$, $\beta$-unsaturated ketones have been reported to act as competitive, selective, and reversible MAO-B inhibitors (Robinson et al., 2013; Mathew et al., 2016; Sasidharan et al., 2016; Sasidharan et al., 2018; Mathew et al., 2019a). However, the effect of introducing the piperazine pharmacophore into the chalcone framework has not been explored in the context of MAO-B inhibition. Previously, new chalcones containing the piperazine or 2,5-dichlorothiophene moiety were synthesized and evaluated for antimicrobial activities (Tomar et al. 2007). Herein, we describe the synthesis of a series of piperazine- derived chalcones and inspected for their abilities to inhibit MAOs, ChEs, and BACE-1 in an effort to identify novel treatments for NDDs.

Page 2/19 


\section{Materials And Methods}

\section{Synthesis}

Derivatives were synthesized using base-catalyzed Claisen-Schmidt condensation reaction between various aromatic aldehydes and 4'-piperazinoacetophenone (Tomar et al., 2007). Briefly, the synthesis was initiated by adding $0.01 \mathrm{M} \mathrm{4'-}$ piperazinoacetophenone to an ethanol $(20 \mathrm{ml}) / 40 \%$ of $\mathrm{KOH}(8 \mathrm{ml})$ mix and then adding $0.01 \mathrm{M}$ of an aromatic benzaldehyde and stirring for 10-12 h (Scheme 1). Resulting solutions were poured into ice-cold water, and the precipitates were washed with water.

\section{Enzyme assays}

Kynuramine $(0.06 \mathrm{mM})$ and benzylamine $(0.3 \mathrm{mM})$ were used as substrates to assay the activities of recombinant human MAO-A and MAO-B, respectively [Mathew et al. 2018]. AChE and butyrylcholinesterase (BChE) activities were assayed using Electrophorus electricus Type VI-S and Equine serum Type, respectively, in the presence of $0.5 \mathrm{mM}$ acetylthiocholine

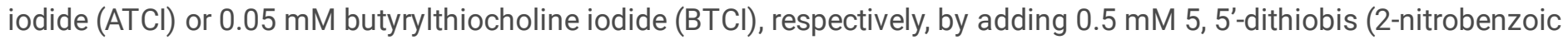
acid) (DTNB) [Ellman et al. 1961; Baek et al. 2018a; Lee et al. 2019]. Enzymes and inhibitors were preincubated for 15 min before measuring inhibitory activities. BACE-1 activity was determined using a $\beta$-secretase (BACE-1) activity detection kit, which included the 7-methoxycoumarin-4-acetyl-[Asn670,Leu671]-amyloid $\beta / A 4$ protein fragment 667-676-(2,4dinitrophenyl) Lys-Arg-Arg amide trifluoroacetate as a substrate. The reaction was performed for $2 \mathrm{~h}$ at $37^{\circ} \mathrm{C}$ and the signals were measured using a fluorescence spectrometer (FS-2, Scinco, Seoul, Korea) with an excitation wavelength of $320 \mathrm{~nm}$ and an emission wavelength of $405 \mathrm{~nm}$. Chemicals, enzymes, and BACE-1 activity detection kits were purchased from Sigma-Aldrich (St. Louis, MO, USA).

\section{Enzyme inhibitory and kinetic studies}

The inhibitory activities of the 11 compounds were initially measured at a concentration of $10 \mu \mathrm{M}$ against MAO-A, MAO-B, $\mathrm{AChE}, \mathrm{BChE}$, or BACE-1. IC $\mathrm{S}_{50}$ values for MAO-A and MAO-B by the compounds were determined first and then those for AChE, BChE, and BACE-1 by compounds with residual activities of $<50 \%$ were investigated. Kinetic studies were carried out on PC10 and PC11, which most potently inhibited MAO-B, at five substrate concentrations and three inhibitor concentrations, as previously described [Cecen et al., 2020].

\section{Inhibitor reversibility analysis}

The reversibility of MAO-B inhibitions by PC10 and PC11 were assessed by dialysis after preincubating them at $0.15 \mu \mathrm{M}$ with MAO-B for 30 min, as described previously [Baek et al. 2018b]. For comparison purposes, MAO-B was preincubated with lazabemide (a reference reversible MAO-B inhibitor) or pargyline (a reference irreversible MAO-B inhibitor) at 0.20 and $0.30 \mu \mathrm{M}$, respectively. Reversibility patterns were assessed by comparing the activities of dialyzed $\left(A_{D}\right)$ and undialyzed $\left(A_{U}\right)$ samples.

\section{ADME prediction}

ADME parameters including pharmacokinetic data and physical properties such as lipophilicity and water solubility of PC10 and PC11 were predicted in silico using free softare available at http://www.swissadme.ch/ (Daina et al., 2017).

\section{Molecular docking}

The 3D-coordinates of MAO-A, MAO-B, and AChE crystals were collected from the Protein Data Bank by selecting 2Z5X, 2V5Z, and 4EY7 entries, respectively (Son et al., 2008; Binda et al., 2012; Cheung et al., 2012). Protein Preparation Wizard tools were employed to optimize and minimize crystal structures (Schrödinger 2020c; Madhavi Sastry et al., 2013). To 
explore the chirality, ionization states, ring conformations, and tautomers of each input structure, PC4, PC10, and PC11 were treated by using the Ligprep tool (Schrödinger 2020b). Docking simulations were carried out using GLIDE (Friesner et al., 2004; Schrödinger 2020a), and the centers of mass of cognate ligands were used to generate the enclosing boxes. The standard precision docking protocol was used with default Force Field OPLS_2005 and detailed analysis of ligand binding affinities was perforemed by calculating binding free energies $(\Delta G)$ between protein and ligands using the Molecular Mechanics/Generalized Born Surface Area (MM-GBSA) method (Banks et al., 2004; Genheden \& Ryde, 2015). The $\Delta G$ values were calculated using: $\Delta G_{\text {bind }}=\Delta E_{\mathrm{MM}}+\Delta G_{\text {solv }}+\Delta G_{\mathrm{SA}}$, where $\Delta E_{\mathrm{MM}}=$ minimized energy of the ligand-protein complex, $\Delta G_{\text {solv }}=$ solvation energy, and $\Delta G_{S A}=$ surface area energy.

\section{Results}

\section{Inhibitory activities against MAOs, ChEs, and BACE-1}

All eleven compounds exhibited high inhibitory activities against MAO-B with residual activities of $<50 \%$ at a concentration of $10 \mu \mathrm{M}$ (Table 1). PC10 exhibited the greatest inhibitory activity against MAO-B $\left(\mathrm{IC}_{50}\right.$ value $\left.=0.65 \mu \mathrm{M}\right)$, followed by PC11, which had an $\mathrm{IC}_{50}$ value of $0.71 \mu \mathrm{M}$. PC1 inhibited MAO-B least $\left(\mathrm{IC}_{50}=7.62 \mu \mathrm{M}\right)$, and the other 8 compounds had $\mathrm{IC}_{50}$ values ranging from 1.09 to $3.65 \mu \mathrm{M}$. A comparison of the $\mathrm{IC}_{50}$ value of PC1 with those of PC10 and PC11 indicated that the presence of a $-\mathrm{F}$ or $-\mathrm{CF}_{3}$ group instead of $-\mathrm{H}$ increased MAO-B inhibitory activity. Other substituents such as $-\mathrm{OCH}_{3}$ of PC3, - $\mathrm{Cl}$ of PC8, and -OH of PC2 moderately enhanced MAO-B inhibition. However, all compounds much less effectively inhibited MAO-A at $10 \mu \mathrm{M}$ wand achieved residual activities of $>65 \%$ (Table 1). PC3 had the lowest IC ${ }_{50}$ value of $27.9 \mu \mathrm{M}$. Regarding selectivity indices (SIs), PC10 and PC11 had the highest values of 48.3 and 49.2, respectively, for MAO-B over MAO-A. 
Table 1

Inhibitions of recombinant human MAO-A, MAO-B, AChE, BChE, and BACE-1 by piperazine-substituted chalcones ${ }^{\mathrm{a}}$

\begin{tabular}{|c|c|c|c|c|c|c|c|c|c|c|c|}
\hline \multirow[t]{2}{*}{ Compounds } & \multicolumn{5}{|c|}{ Residual activity at $10 \mu \mathrm{M}(\%)$} & \multicolumn{5}{|c|}{$\mathrm{IC}_{50}(\mu \mathrm{M})$} & \multirow[t]{2}{*}{$S I^{b}$} \\
\hline & $\underset{A}{\text { MAO- }}$ & $\begin{array}{l}\text { MAO- } \\
\text { B }\end{array}$ & AChE & BChE & $\begin{array}{l}\text { BACE- } \\
1\end{array}$ & MAO-A & MAO-B & AChE & BChE & $\begin{array}{l}\text { BACE- } \\
1\end{array}$ & \\
\hline PC1 & $\begin{array}{l}96.6 \\
\pm \\
4.77\end{array}$ & $\begin{array}{l}40.6 \\
\pm \\
3.93\end{array}$ & $\begin{array}{l}72.9 \\
\pm \\
3.84\end{array}$ & $\begin{array}{l}96.0 \\
\pm \\
4.86\end{array}$ & $\begin{array}{l}90.6 \\
\pm 0.11\end{array}$ & $>40$ & $\begin{array}{l}7.62 \pm \\
0.70\end{array}$ & - & - & - & $\begin{array}{l}> \\
5.25\end{array}$ \\
\hline PC2 & $\begin{array}{l}76.4 \\
\pm \\
1.59\end{array}$ & $\begin{array}{l}13.3 \\
\pm \\
3.14\end{array}$ & $\begin{array}{l}56.8 \\
\pm \\
0.96\end{array}$ & $\begin{array}{l}97.1 \\
\pm \\
1.87\end{array}$ & $\begin{array}{l}51.2 \\
\pm \\
0.060\end{array}$ & $\begin{array}{l}30.1 \pm \\
0.14\end{array}$ & $\begin{array}{l}1.56 \pm \\
0.14\end{array}$ & - & - & $\begin{array}{l}9.86 \pm \\
0.10\end{array}$ & 19.3 \\
\hline PC3 & $\begin{array}{l}65.7 \\
\pm \\
1.80\end{array}$ & $\begin{array}{l}15.0 \\
\pm \\
0.79\end{array}$ & $\begin{array}{l}58.8 \\
\pm \\
3.20\end{array}$ & $\begin{array}{l}94.2 \\
\pm \\
1.50\end{array}$ & $\begin{array}{l}28.9 \\
\pm 0.27\end{array}$ & $\begin{array}{l}27.9 \pm \\
0.55\end{array}$ & $\begin{array}{l}1.09 \pm \\
0.21\end{array}$ & - & - & $\begin{array}{l}6.72 \pm \\
0.061\end{array}$ & 25.6 \\
\hline PC4 & $\begin{array}{l}82.9 \\
\pm \\
7.20\end{array}$ & $\begin{array}{l}29.5 \\
\pm \\
1.93\end{array}$ & $\begin{array}{l}43.4 \\
\pm \\
2.61\end{array}$ & $\begin{array}{l}99.8 \\
\pm \\
0.31\end{array}$ & $\begin{array}{l}55.5 \\
\pm 0.34\end{array}$ & $\begin{array}{l}29.4 \pm \\
1.22\end{array}$ & $\begin{array}{l}2.72 \pm \\
0.32\end{array}$ & $\begin{array}{l}8.77 \pm \\
0.20\end{array}$ & - & $\begin{array}{l}15.5 \pm \\
0.088\end{array}$ & 10.8 \\
\hline PC5 & $\begin{array}{l}80.1 \\
\pm \\
1.96\end{array}$ & $\begin{array}{l}23.2 \\
\pm \\
0.64\end{array}$ & $\begin{array}{l}64.2 \\
\pm \\
2.98\end{array}$ & $\begin{array}{l}93.7 \\
\pm \\
8.26\end{array}$ & $\begin{array}{l}49.3 \\
\pm 0.83\end{array}$ & $\begin{array}{l}34.1 \pm \\
2.51\end{array}$ & $\begin{array}{l}2.31 \pm \\
0.46\end{array}$ & - & - & $\begin{array}{l}11.6 \pm \\
0.0011\end{array}$ & 14.8 \\
\hline PC6 & $\begin{array}{l}93.1 \\
\pm \\
0.65\end{array}$ & $\begin{array}{l}27.3 \\
\pm \\
3.86\end{array}$ & $\begin{array}{l}63.2 \\
\pm \\
2.23\end{array}$ & $\begin{array}{l}82.9 \\
\pm \\
5.82\end{array}$ & $\begin{array}{l}61.0 \\
\pm 0.71\end{array}$ & $\begin{array}{l}35.6 \pm \\
1.24\end{array}$ & $\begin{array}{l}2.59 \pm \\
0.18\end{array}$ & - & - & $\begin{array}{l}16.4 \pm \\
0.011\end{array}$ & 13.8 \\
\hline PC7 & $\begin{array}{l}98.1 \\
\pm \\
5.24\end{array}$ & $\begin{array}{l}35.1 \\
\pm \\
1.75\end{array}$ & $\begin{array}{l}62.8 \\
\pm \\
1.07\end{array}$ & $\begin{array}{l}98.7 \\
\pm \\
4.40\end{array}$ & $\begin{array}{l}90.0 \\
\pm 0.71\end{array}$ & $\begin{array}{l}35.3 \pm \\
2.51\end{array}$ & $\begin{array}{l}3.65 \pm \\
0.47\end{array}$ & - & - & - & 9.67 \\
\hline PC8 & $\begin{array}{l}99.2 \\
\pm \\
2.62\end{array}$ & $\begin{array}{l}11.6 \\
\pm \\
1.17\end{array}$ & $\begin{array}{l}61.4 \\
\pm \\
2.14\end{array}$ & $\begin{array}{l}94.7 \\
\pm \\
2.51\end{array}$ & $\begin{array}{l}40.3 \\
\pm 0.38\end{array}$ & $>40$ & $\begin{array}{l}1.37 \pm \\
0.027\end{array}$ & - & - & $\begin{array}{l}9.76 \pm \\
0.041\end{array}$ & $\begin{array}{l}> \\
29.2\end{array}$ \\
\hline PC9 & $\begin{array}{l}98.6 \\
\pm \\
7.86\end{array}$ & $\begin{array}{l}26.9 \\
\pm \\
0.58\end{array}$ & $\begin{array}{l}71.2 \\
\pm \\
1.07\end{array}$ & $\begin{array}{l}89.1 \\
\pm \\
0.31\end{array}$ & $\begin{array}{l}105.0 \\
\pm 0.93\end{array}$ & $>40$ & $\begin{array}{l}3.07 \pm \\
0.81\end{array}$ & - & - & - & $\begin{array}{l}> \\
13.0\end{array}$ \\
\hline PC10 & $\begin{array}{l}94.5 \\
\pm \\
7.79\end{array}$ & $\begin{array}{l}9.91 \\
\pm \\
1.27\end{array}$ & $\begin{array}{l}72.1 \\
\pm \\
0.10\end{array}$ & $\begin{array}{l}69.6 \\
\pm \\
0.31\end{array}$ & $\begin{array}{l}51.1 \\
\pm 0.74\end{array}$ & $\begin{array}{l}31.4 \pm \\
3.50\end{array}$ & $\begin{array}{l}0.65 \pm \\
0.023\end{array}$ & $\begin{array}{l}28.0 \pm \\
2.43\end{array}$ & $\begin{array}{l}36.4 \pm \\
2.36\end{array}$ & $\begin{array}{l}14.9 \pm \\
0.36-\end{array}$ & 48.3 \\
\hline PC11 & $\begin{array}{l}80.9 \\
\pm \\
4.19\end{array}$ & $\begin{array}{l}10.4 \\
\pm \\
0.64\end{array}$ & $\begin{array}{l}68.4 \\
\pm \\
2.41\end{array}$ & $\begin{array}{l}70.9 \\
\pm \\
0.31\end{array}$ & $\begin{array}{l}52.2 \\
\pm 0.31\end{array}$ & $\begin{array}{l}34.9 \pm \\
4.10\end{array}$ & $\begin{array}{l}0.71 \pm \\
0.0035\end{array}$ & $\begin{array}{l}26.3 \pm \\
1.29\end{array}$ & $\begin{array}{l}36.2 \pm \\
3.65\end{array}$ & $\begin{array}{l}15.3 \pm \\
0.89\end{array}$ & 49.2 \\
\hline Toloxatone & & & & & & $\begin{array}{l}1.08 \pm \\
0.025\end{array}$ & - & - & - & - & \\
\hline Lazabemide & & & & & & - & $\begin{array}{l}0.11 \pm \\
0.016\end{array}$ & - & - & - & \\
\hline
\end{tabular}

\footnotetext{
a Results are expressed as the means \pm standard errors of experiments performed in duplicate or triplicate.

b SI values were calculated by dividing $\mathrm{IC}_{50}$ values for MAO-A by MAO-B values.

Values for reference compounds were determined after preincubating them for 30 min with enzymes.
} 


\begin{tabular}{|c|c|c|c|c|c|c|c|c|c|c|c|}
\hline \multirow[t]{2}{*}{ Compounds } & \multicolumn{5}{|c|}{ Residual activity at $10 \mu \mathrm{M}(\%)$} & \multicolumn{5}{|c|}{$\mathrm{IC}_{50}(\mu \mathrm{M})$} & \multirow[t]{2}{*}{$\mathrm{SI}^{\mathrm{b}}$} \\
\hline & $\begin{array}{l}\text { MAO- } \\
A\end{array}$ & $\begin{array}{l}\text { MAO- } \\
B\end{array}$ & AChE & BChE & $\begin{array}{l}\text { BACE- } \\
1\end{array}$ & MAO-A & MAO-B & AChE & BChE & $\begin{array}{l}\text { BACE- } \\
1\end{array}$ & \\
\hline Clorgyline & & & & & & $\begin{array}{l}0.0070 \\
\pm \\
0.00070\end{array}$ & - & - & - & - & \\
\hline Pargyline & & & & & & - & $\begin{array}{l}0.14 \pm \\
0.0059\end{array}$ & - & - & - & \\
\hline Tacrine & & & & & & - & - & $\begin{array}{l}0.27 \pm \\
0.019\end{array}$ & $\begin{array}{l}0.060 \\
\pm \\
0.0022\end{array}$ & - & \\
\hline Donepezil & & & & & & - & - & $\begin{array}{l}0.0095 \\
\pm \\
0.0019\end{array}$ & $\begin{array}{l}0.18 \pm \\
0.0038\end{array}$ & - & \\
\hline Quercetin & & & & & & - & - & - & - & $\begin{array}{l}13.4 \pm \\
0.035\end{array}$ & \\
\hline \multicolumn{12}{|c|}{ a Results are expressed as the means \pm standard errors of experiments performed in duplicate or triplicate. } \\
\hline \multicolumn{12}{|c|}{ b SI values were calculated by dividing $\mathrm{IC}_{50}$ values for MAO-A by MAO-B values. } \\
\hline
\end{tabular}

All compounds weakly to moderately inhibited AChE and BChE by $<50 \%$ at of $10 \mu \mathrm{M}$, except PC4, which inhibited AChE by $56.6 \%\left(\mathrm{IC}_{50}=8.77 \mu \mathrm{M}\right)$ (Table 1). PC10 and PC11 had IC 50 values of 28.0 and $26.3 \mu \mathrm{M}$, respectively, for AChE, and showed moderate inhibitory activities against $B C h E$ with $\mathrm{IC}_{50}$ values of 36.4 and $36.2 \mu \mathrm{M}$, respectively. Interestingly, some of the compounds effectively inhibited BACE-1 (Table 1). PC3 best inhibited BACE-1, and PC10 and PC11 showed moderate BACE-1 inhibitory activities with $\mathrm{IC}_{50}$ values of 14.9 and $15.3 \mu \mathrm{M}$, respectively; these two compounds contained fluoro and trifluoromethyl pharmacophores, respectively, on a piperazine-substituted chalcone framework.

\section{MAO-B inhibition and its kinetics}

MAO-B inhibitions by PC10 and PC11 were subjected to kinetic analysis. Lineweaver-Burk and secondary plots showed that PC10 and PC11 competitively inhibited MAO-B (Figs. $1 \mathrm{~A}$ and $\mathrm{C}$ ), with $\mathrm{K}_{\mathrm{i}}$ values of $0.63 \pm 0.13$ and $0.53 \pm 0.068 \mu \mathrm{M}$, respectively (Figs. 2B and D). These experimental observations showed that PC10 and PC11 are competitive and selective inhibitors of MAO-B.

\section{Reversibility studies of MAO-B inhibition}

MAO-B inhibitions by PC10 and PC11 were also subjected to reversibility studies. The results obtained showed that inhibition of MAO-B by PC10 recovered after dialysis from 32.1 ( $A_{U}$ value) to $81.2 \%\left(A_{D}\right.$ value), and that inhibition by PC11 recovered from $32.6\left(A_{U}\right)$ to $68.9 \%\left(A_{D}\right)$. These values were close to those of the reversible reference lazabemide (from 28.3 to $86.9 \%)$. On the other hand, inhibition of MAO-B by the irreversible reference pargyline was not recovered by dialysis (from 31.8 to 32.7\%) (Fig. 2). The above data revealed that MAO-B inhibitions by PC10 and PC11 were recovered to reversible reference values and showed that PC10 and PC11 reversibly inhibit MAO-B.

\section{Adme Prediction}

In silico ADME prediction revealed that PC10 and PC11 fully complied with the limits of Lipinski's rule and supported their oral use and drug-likenesses (Table 2). In addition, the boiled-egg and bioavailability radar plots generated by the 
SwissADME tool also provided two clear ADME characteristics (Fig. 3). Boiled-egg pictures represent passive absorption in the gastrointestinal (GI) tract (shown as the white area) and ability to cross the blood-brain barrier (BBB; yellow area). These plots showed that PC10 and PC11 were located in the yellow area, suggesting ability to cross the BBB, and indicated that both would be passively absorbed in the GI system (Figs. 3a and b). Bioavailability radar also placed the drug-likeness representation of PC11 within the pink area, which is an indicator of optimal physicochemical properties, such as size, polarity, solubility, lipophilicity, saturation, and suitability for oral administration. In this respect, PC10 showed a slight deviation in physicochemical property of saturation (Figs. 3c and d).

Table 2

ADME predictions for PC10 and PC11

\begin{tabular}{|c|c|c|}
\hline Properties & PC10 & PC11 \\
\hline No. H-bond acceptor & 3 & 5 \\
\hline No. H-bond donor & 1 & 1 \\
\hline $\log _{\mathrm{O} / \mathrm{W}}(\mathrm{iLOGP})$ & 2.97 & 3.30 \\
\hline No. rotatable bonds & 4 & 5 \\
\hline TPSA & 32.34 & 32.34 \\
\hline $\operatorname{LogK}_{\mathrm{P}}$ (skin permeation) & -7.39 & -6.96 \\
\hline Lipinski's rule violation & No & No \\
\hline Bioavailability score & 0.55 & 0.55 \\
\hline GI absorption & Yes & Yes \\
\hline BBB permeation & High & Yes \\
\hline PAINS alerts & Zero & Zero \\
\hline P-pg substrate & No & No \\
\hline
\end{tabular}

\section{Molecular Docking Studies}

Molecular docking simulations and binding free energies calculations were carried out to investigate molecular interactions between PC4, PC10, or PC11 and the binding sites of MAOs and AChE. PC10 and PC11 had docking scores of -5.73 and $-4.81 \mathrm{kcal} / \mathrm{mol}$, respectively, towards MAO-A, and of -7.29 and $-7.11 \mathrm{kcal} / \mathrm{mol}$, respectively, towards MAO-B (Table 3). In addition, the MM-GBSA values of PC10 and PC11 were -28.77 and $-52.60 \mathrm{kcal} / \mathrm{mol}$, respectively, towards MAO-A, and -64.19 and $66.06 \mathrm{kcal} / \mathrm{mol}$, respectively, towards MAO-B (Table 3). Regarding AChE inhibition, although docking simulation returned comparable scores for the three compounds, PC4 had the lowest binding free energy (i.e., $-55.81,-39.82$, and $-52.18 \mathrm{kcal} / \mathrm{mol}$ for PC4, PC10, and PC11, respectively) (Table 3). 
Table 3

Docking scores and MM-GBSA values for interaction between PC4, PC10, or PC11 and MAO-A, MAO-B, or AChE.

\begin{tabular}{|lllllll|}
\hline Compounds & \multicolumn{3}{c}{ Docking Score $(\mathrm{kcal} / \mathrm{mol})$} & \multicolumn{3}{c|}{ MM-GBSA (kcal/mol) } \\
\cline { 2 - 7 } & MAO-A & MAO-B & AChE & MAO-A & MAO-B & AChE \\
\hline PC4 & -5.85 & -7.29 & -6.10 & -12.43 & -66.34 & -55.81 \\
\hline PC10 & -5.73 & -7.29 & -6.25 & -28.77 & -64.19 & -39.82 \\
\hline PC11 & -4.81 & -7.11 & -5.97 & -52.60 & -66.06 & -52.18 \\
\hline
\end{tabular}

The para-methyl and para-fluorine rings of PC4 and PC10 faced FAD and interacted through $\pi-\pi$ contacts with $Y 407$ of MAO-A (Fig. 4A). Conversely, although slightly larger, the - $\mathrm{CF}_{3}$ substituent of PC11 did not allow its styrene moiety to face FAD, which resulted in the phenyl ring of chalcone establishing $\pi-\pi$ interactions with F208 of MAO-A. All three compounds assumed similar binding poses within the MAO-B binding pocket (Fig. 4B), which was ascribed to the existence of two $\pi-\pi$ interactions between chalcone aromatic rings and Y398 or Y326 of MAO-B selective residues. The styrene portion of PC4 established a $\pi-\pi$ interaction with Y341 of AChE and the carbonyl group of its chalcone moiety formed a hydrogen bond with F295 of AChE (Fig. 4C). On the other hand, the chalcone moieties of PC10 and PC11 formed $\pi-\pi$ interactions with W286 and hydrogen bonds with the main chain of F295.

\section{Discussion}

Chalcones are considered versatile scaffolds for many of the CNS-related agents, such as anti-depressants, anxiolytics, $\beta$ amyloid plaque imaging agents, adenosine receptor antagonists, and MAO-B and AChE inhibitors (Mathew et al., 2019b). The three rotatable bonds available in the Michael acceptor between the two phenyl systems of chalcones provide different mode interactions in the inhibitor binding cavities of the enzymes, which are highly dependent on the natures and bulkinesses of groups bearing on the $\mathbf{A}$ and $\mathbf{B}$ chalcone rings (Matos et al., 2015).

Recent studies have reported that the presence of electron-donating groups, such as methyl, methoxy, ethyl, dimethylamino, and ethyl acetohydroxamate, at the para position of the phenyl B ring of chalcones confers greater MAO-B inhibition than MAO-A inhibition. Lipophilic halogen atoms (fluorine, chlorine, and bromine) at the same position also resulted in outstanding MAO-B inhibition (Morales-Camilo et al., 2015; Reeta et al., 2019; Shalaby et al., 2019). In addition, the presence of an aliphatic or methyl containing amino group or a nitrogen-derived pharmacophore in chalcones is required for AChE inhibition (Liu et al., 2016; Xiao et al., 2017; Bai et al., 2019). In this respect, the present design strategy explores the effects of the presence of both pharmacophores in the chalcone framework (Fig. 5) by introducing a piperazine nucleus at the para position of the phenyl A ring and various electron-donating and other substituents on the $\mathbf{B}$ ring of the chalcone scaffold. Recently, Sasidharan et al. reported that morpholine-bearing chalcones exhibited dual-acting inhibitory activities, i.e., selective MAO-B inhibition with moderate AChE inhibition (Sasidharan et al. 2021).

In the present study, the unsubstituted piperazine-based chalcone (PC1) exhibited moderate MAO-B inhibition with an IC ${ }_{50}$ value of $7.62 \mu \mathrm{M}$ but high residual activities for MAO-A, AChE, BChE, and BACE-1 (96.6\%, 72.9\%, 96.0\%, and 90.6\%, respectively) at $10 \mu \mathrm{M}$. The substitutions of small groups on the B ring of the phenyl system slightly impacted activity ratio toward multi-targets, which emphasizes the importance of substituents on the B ring. Some interesting structure-activity relationships (SARs) were derived, as depicted in Fig. 6.

The SAR studies revealed that all piperazine-substituted chalcones inhibited MAO-B substantially or moderately better than MAO-A. The existence of electron-withdrawing groups like trifluoromethyl or fluorine provided good MAO-B inhibition and the presence of a methyl group (electron-donating) an the para position of the phenyl B ring provided optimal activity as exemplified by PC4, which had $\mathrm{IC}_{50}$ values for MAO-B and AChE of 2.72 and $8.77 \mu \mathrm{M}$, respectively, and inhibited BACE-1 by 
$44.5 \%$ at $10 \mu \mathrm{M}$. Whereas the introduction of electron-donating groups like methyl (PC4), hydroxyl (PC2), or methoxy (PC3) groups resulted in moderate AChE inhibition (residual activities of $43.4 \%, 56.8 \%$, and $58.8 \%$, respectively, at $10 \mu \mathrm{M}$ ). Moreover, these electron-donating groups showed moderately selective inhibition of MAO-B. Regarding the effects of halogen substitution at phenyl ring on MAO-B inhibition, fluorine (PC10) had a greater effect than chlorine (PC8) or bromine (PC9). The high electronegativity of fluorine substituted phenyl in various molecular frameworks has been recently reported to increase hydrophobic interactions with Tyr398 and Tyr435 markedly in the active site of MAO-B (Mathew et al., 2020).

MAO-B, AChE, and BACE-1 are important enzyme targets and can produce neurotoxic free radical by-products, degrade acetylcholine, and generate amyloid $\beta(A \beta)$, and thus, the development of highly selective ligands that target these enzymes is of considerable interest to those involved in the development of drugs for AD (Moussa-Pacha et al., 2019; Benny and Thomas, 2019). Recently, many researchers have used ligand or structure-based drug strategies to design dualacting MAO-B/AChE inhibitors (Mathew, 2020). However, this is the first study to focus on the inhibitory profiles of heterocycle containing chalcone-based compounds on MAO-A, MAO-B, AChE, BChE, and BACE-1. Our findings show that the lead molecules PC4, PC10, and PC11 selectively inhibit MAO-B at the submicromolar level and moderately inhibit AChE and BACE-1.

Reversible MAO-B inhibitors have shorter action durations than irreversible inhibitors because they dissociate from targets (Tripton 2018). Many new reversible MAO-B inhibitors have been developed using various structural scaffolds, such as chromones, coumarins, chalcones, phenyloxazolidinones, and pyrazolines (Carradori \& Silvestri 2015; Mathew, 2017; Mathew, 2020). Our reversibility studies on PC10 or PC11 inhibition of MAO-B indicate that the reversible natures of their interactions cause minimal target disruption and provide improved ADME profiles.

Computational results of interactions between PC4, PC10, or PC11 and MAO-A, MAO-B, or AChE targets provided satisfactory explanations of experimental data and agreed well with experimental $I_{50}$ values. Furthermore, they showed that $\pi-\pi$ interaction with Y326 of MAO-B (a selective residue), which is changed to I335 in MAO-A (Mangiatordi et al., 2017), is a prerequisite for interaction in its binding pocket, as previously reported (Oh et al., 2020).

\section{Conclusion}

We report the results of an investigation of the neuro-related, multi-enzyme targeting profiles of piperazine-bearing a, $\beta$ unsaturated ketones. The abilities of MAOs and ChEs inhibitions by the compounds were found to depend on the natures of substituents at the para position of the B phenyl ring of the chalcone framework. All eleven compounds inhibited MAO-B more than MAO-A, and compounds PC4, PC10, and PC11 potentially inhibited MAO-B with IC $\mathrm{C}_{50}$ values of $2.72,0.65$, and $0.71 \mu \mathrm{M}$, respectively, and moderately inhibited $A C h E$ with $\mathrm{IC}_{50}$ values of $8.77,28.0$, and $26.3 \mu \mathrm{M}$, respectively. Furthermore, these experimental results were also supported by molecular docking studies. In addition, PC4, PC10, and PC11 moderately inhibited BACE-1 with $\mathrm{IC}_{50}$ values of $15.5,14.9$, and $15.3 \mu \mathrm{M}$, respectively, which further supports their potential use for the development of novel drugs against various neurological disorders.

\section{Declarations}

\section{Compliance with ethical standards}

\section{Conflict of interest}

The authors declare that they have no conflict of interest

\section{Funding}


This work was supported by the Amrita Vishwa Vidyapeetham University. Seed Grant Number: K-PHAR-20-628 (B. Mathew). This research was also supported by the King Saud University, Riyadh, Saudi Arabia (Project No. RSP 2020/200 to S. Al-Rashed)

\section{Author contributions}

B. Mathew synthesized the molecules, planned the study and edited the manuscript. J.M.Oh, H. Kim performed the biological evaluation. S.Al-Rashid, G.E. Batiha, D.G.T. Parambi, N. Gambacorta, O. Nicolotti conducted the computational studies. Data curation and writing the original draft preparation done by B. Mathew and $\mathrm{H}$. Kim

\section{Data availability}

The datasets used and analysed during the current study are available from the corresponding author on reasonable request.

\section{Compliance with ethical standards}

Competing interests The authors declare that they have no competing interests.

Ethics approval and consent to participate Not applicable.

Consent for publication Not applicable.

\section{References}

1. Baek SC, Park MH, Ryu HW, Lee JP, Kang MG, Park D, Park CM, Oh SR, Kim H (2018a). Rhamnocitrin isolated from Prunus padus var. seoulensis: A potent and selective reversible inhibitor of human monoamine oxidase A. Bioorg Chem 28:317-325.

2. Baek SC, Lee HW, Ryu HW, Kang MG, Park D, Kim SH, Cho ML, Oh SR, Kim H (2018b). Selective inhibition of monoamine oxidase A by hispidol. Bioorg Med Chem Lett 15:584-588.

3. Bai P, Wang K, Zhang P, Shi J, Cheng X, Zhang Q, Zheng C, Cheng Y, Yang J, Lu X, Sang Z (2019). Development of chalcone-O-alkylamine derivatives as multifunctional agents against Alzheimer's disease. Eur J Med Chem 183:111737.

4. Banks JL, Beard HS, Cao Y, Cho AE, Damm W, Farid R, Felts AK, Halgren TA, Mainz DT, Maple JR, Murphy R, Philipp DM, Repasky MP, Zhang LY, Berne BJ, Friesner RA, Gallicchio E, Levy RM (2005). Integrated Modeling Program, Applied Chemical Theory (IMPACT). J Comput Chem 26:1752-1780.

5. Barnham KJ, Masters CL, Bush Al (2004). Neurodegenerative diseases and oxidative stress. Nat Rev Drug Discov 3:205-214.

6. Benny A, Thomas J (2019). Essential oil as treatment for Alzheimer's disease: Current and future perspectives. Planta Med 85:239-248.

7. Binda C, Wang J, Pisani L, Caccia C, Carotti A, Salvati P, Edmondson DE, Mattevi A (2007). Structures of human monoamine oxidase $B$ complexes with selective noncovalent inhibitors: safinamide and coumarin analogs. J Med Chem 50: 5848-5852.

8. Brito AF, Moreira LKS, Menegatti R, Costa EA (2019). Piperazine derivatives with central pharmacological activity used as therapeutic tools. Fundam Clin Pharmacol 33:13-24.

9. Carradori S, Silvestri R (2015). New frontiers in selective human MAO-B inhibitors. J Med Chem 58:6717-32.

10. Çeçen M, Oh JM, Özdemir Z, Büyüktuncel SE, Uysal M, Abdelgawad MA, Musa A, Gambacorta N, Nicolotti O, Mathew B, Kim H (2020). Design, synthesis, and biological evaluation of pyridazinones containing the (2-Fluorophenyl) 
Piperazine Moiety as Selective MAO-B Inhibitors. Molecules. 25:5371.

11. Cheung J, Rudolph MJ, Burshteyn F, Cassidy MS, Gary EN, Love J, Franklin MC, Height JJ (2012). Structures of human acetylcholinesterase in complex with pharmacologically important ligands. J Med Chem 55:10282-10286.

12. Chimenti F, Fioravanti R, Bolasco A, Chimenti P, Secci D, Rossi F, Yáñez M, Orallo F, Ortuso F, Alcaro S (2009). Chalcones: A valid scaffold for monoamine oxidases inhibitors J Med Chem 52:2818-2824.

13. Daina A, Michielin O, Zoete V (2017). SwissADME: A free web tool to evaluate pharmacokinetics, drug-likeness and medicinal chemistry friendliness of small molecules. Sci Rep 7:42717.

14. Ellman GL, Courtney KD, Andres V Jr, Feather-Stone RM (1961). A new and rapid colorimetric determination of acetylcholinesterase activity. Biochem Pharmacol 7:88-95.

15. Friesner RA, Banks JL, Murphy RB, Halgren TA, Klicic JJ, Mainz DT, Repasky MP, Knoll EH, Shelley M, Perry JK, Shaw DE, Francis P, Shenkin PS. (2004) Glide: A new approach for rapid, accurate docking and scoring. 1. Method and assessment of docking accuracy. J Med Chem 47:1739-1749.

16. Geldenhuys WJ, Youdim MB, Carroll RT, Van der Schyf CJ (2011). The emergence of designed multiple ligands for neurodegenerative disorders. Prog Neurobiol 94:347-359.

17. Genheden S, Ryde U (2015). The MM/PBSA and MM/GBSA Methods to Estimate Ligand-Binding Affinities. Expert Opin Drug Discov 10: 449-461.

18. Guglielmi P, Mathew B, Secci D, Carradori S (2020). Chalcones: Unearthing their therapeutic possibility as monoamine oxidase B inhibitors. Eur J Med Chem 205:112650.

19. Jevtić II, Lai TH, Penjišević JZ, Dukić-Stefanović S, Andrić DB, Brust P, Kostić-Rajačić SV, Teodoro R (2020). Newly synthesized fluorinated cinnamylpiperazines possessing low in vitro MAO-B binding. Molecules 25:4941.

20. Kaya B, Yurttaş L, Sağlik BN, Levent S, Özkay Y, Kaplancikli ZA (2017). Novel 1-(2-pyrimidin-2-yl)piperazine derivatives as selective monoamine oxidase (MAO)-A inhibitors. J Enzyme Inhib Med Chem 32:193-202.

21. Kumar B, Sheetal, Mantha AK, Kumar V (2018). Synthesis, biological evaluation and molecular modeling studies of phenyl-/benzhydrylpiperazine derivatives as potential MAO inhibitors. Bioorg Chem 77:252-262.

22. Lee JP, Kang MG, Lee JY, Oh JM, Baek SC, Leem HH, Park D, Cho ML, Kim H (2019). Potent inhibition of acetylcholinesterase by sargachromanol I from Sargassum siliquastrum and by selected natural compounds. Bioorg Chem 89:103043.

23. Lin MT, Beal MF (2006). Mitochondrial dysfunction and oxidative stress in neurodegenerative diseases. Nature 443:787-795.

24. Liu H, Fan H, Gao X, Huang X, Liu X, Liu L, Zhou C, Tang J, Wang Q, Liu W (2016). Design, synthesis and preliminary structure-activity relationship investigation of nitrogen-containing chalcone derivatives as acetylcholinesterase and butyrylcholinesterase inhibitors: a further study based on Flavokawain B Mannich base derivatives. J Enzyme Inhib Med Chem 31:580-589.

25. Madhavi Sastry G, Adzhigirey M, Day T, Annabhimoju R, Sherman W (2013). Protein and Ligand Preparation: Parameters, Protocols, and Influence on Virtual Screening Enrichments. J Comput Aided Mol Des 27: 221-234.

26. Mangiatordi GF, Alberga D, Pisani L, Gadaleta D, Trisciuzzi D, Farina R, Carotti A, Lattanzi G, Catto M, Nicolotti 0 (2017). A rational approach to elucidate human monoamine oxidase molecular selectivity. Eur J Pharm Sci 101:9099.

27. Mathew B (2020). Privileged Pharmacophore of FDA Approved Drugs in Combination with Chalcone Framework: A New Hope for Alzheimer's Treatment. Comb Chem High Throughput Screen 23:842-846.

28. Mathew B, Baek SC, Grace Thomas Parambi D, Lee JP, Joy M, Annie Rilda PR, Randev RV, Nithyamol P, Vijayan V, Inasu ST, Mathew GE, Lohidakshan KK, Kumar Krishnan G, Kim H (2018). Selected aryl thiosemicarbazones as a new class of multi-targeted monoamine oxidase inhibitors. MedChemComm 9:1871-1881. 
29. Mathew B, Baek SC, Thomas Parambi DG, Lee JP, Mathew GE, Jayanthi S, Vinod D, Rapheal C, Devikrishna V, Kondarath SS, Uddin MS, Kim H (2019a). Potent and highly selective dual-targeting monoamine oxidase-B inhibitors: Fluorinated chalcones of morpholine versus imidazole. Arch Pharm (Weinheim) 352:e1800309.

30. Mathew B, Carradori S, Guglielmi P, Uddin MS, Kim H (2020). New Aspects of Monoamine oxidase B inhibitors: The key role of halogens to open the golden door. Curr Med Chem. oi: 10.2174/0929867327666200121165931.

31. Mathew B, Haridas A, Uçar G, Baysal I, Adeniyi AA, Soliman ME, Joy M, Mathew GE, Lakshmanan B, Jayaprakash V (2016). Exploration of chlorinated thienyl chalcones: A new class of monoamine oxidase-B inhibitors. Int J Biol Macromol 91:680-695.

32. Mathew B, Mathew GE, Petzer JP, Petzer A (2017). Structural Exploration of Synthetic Chromones as Selective MAO-B Inhibitors: A Mini Review. Comb Chem High Throughput Screen 20:522-532.

33. Mathew B, Parambi DGT, Sivasankarapillai VS, Uddin MS, Suresh J, Mathew GE, Joy M, Marathakam A, Gupta SV (2019b). Perspective Design of Chalcones for the Management of CNS Disorders: A Mini-Review. CNS Neurol Disord Drug Targets 18:432-445.

34. Matos MJ, Vazquez-Rodriguez S, Uriarte E, Santana L (2015). Potential pharmacological uses of chalcones: a patent review (from June 2011 - 2014). Expert Opin Ther Pat 25:351-366.

35. Modh RP, Kumar SP, Jasrai YT, Chikhalia KH (2013). Design, synthesis, biological evaluation, and molecular modeling of coumarin-piperazine derivatives as acetylcholinesterase inhibitors. Arch Pharm (Weinheim) 346:793-804.

36. Morales-Camilo N, Salas CO, Sanhueza C, Espinosa-Bustos C, Sepúlveda-Boza S, Reyes-Parada M, Gonzalez-Nilo F, Caroli-Rezende M, Fierro A (2015). Synthesis, Biological Evaluation, and Molecular Simulation of Chalcones and Aurones as Selective MAO-B Inhibitors. Chem Biol Drug Des 85:685-95.

37. Moussa-Pacha NM, Abdin SM, Omar HA, Alniss H, Al-Tel TH (2019). BACE1 inhibitors: Current status and future directions in treating Alzheimer's disease. Med Res Rev 40:339-384.

38. Oh JM, Rangarajan TM, Chaudhary R, Singh RP, Singh M, Singh RP, Tondo AR, Gambacorta N, Nicolotti, O, Mathew B, $\mathrm{Kim} \mathrm{H}$ (2020). Novel class of chalcone oxime ethers as potent monoamine oxidase-B and acetylcholinesterase inhibitors. Molecules 25:2356.

39. Özdemir Z, Alagöz MA, Uslu H, Karakurt A, Erikci A, Ucar G, Uysal M (2020). Synthesis, molecular modelling and biological activity of some pyridazinone derivatives as selective human monoamine oxidase-B inhibitors. Pharmacol Rep 72:692-704.

40. Pettersson F, Svensson P, Waters S, Waters N, Sonesson C (2012). Synthesis and evaluation of a set of parasubstituted 4-phenylpiperidines and 4-phenylpiperazines as monoamine oxidase (MAO) inhibitors. J Med Chem 55:3242-3249.

41. Rathi AK, Syed R, Shin HS, Patel RV (2016). Piperazine derivatives for therapeutic use: a patent review (2010-present). Expert Opin Ther Pat 26:777-797.

42. Reeta, Baek SC, Lee JP, Rangarajan TM, Ayushee, Singh RP, Singh M, Mangiatordi GF, Nicolotti O, Kim H, Mathew B (2019). Ethyl Acetohydroxamate Incorporated Chalcones: Unveiling a novel class of chalcones for multitarget monoamine oxidase-B inhibitors against Alzheimer's disease. CNS Neurol Disord Drug Targets 18:643-654.

43. Robinson SJ, Petzer JP, Petzer A, Bergh JJ, Lourens AC (2013). Selected furanochalcones as inhibitors of monoamine oxidase. Bioorg Med Chem Lett 23:4985-9.

44. Sağlık BN, Cebeci O, Acar Çevik U, Osmaniye D, Levent S, Kaya Çavuşoğlu B, Ilgın S, Özkay Y, Kaplancıklı ZA (2020) Design, synthesis, in vitro and in silico studies of new thiazolylhydrazine-piperazine derivatives as selective MAO-A inhibitors. Molecules 25:E4342.

45. Sahin Z, Ertas M, Bender C, Bülbül EF, Berk B, Biltekin SN, Yurttaş L, Demirayak Ş (2018).Thiazole-substituted benzoylpiperazine derivatives as acetylcholinesterase inhibitors. Drug Dev Res 79:406-425.

Page $12 / 19$ 
46. Sasidharan R, Baek SC, Sreedharannair Leelabaiamma M, Kim H, Mathew B (2018). Imidazole bearing chalcones as a new class of monoamine oxidase inhibitors. Biomed Pharmacother 106:8-13.

47. Sasidharan R, Eom BH,Heo JH, Park JE, Abdelgawad MA, Musa A, Gambacorta N, Nicolotti O, Manju SL, Mathew B, Kim H (2021). Morpholine based chalcones as dual acting monoamine oxidase-B and acetylcholinesterase inhibitors. Synthesis and biochemical investigations. J Enzyme Inhib Med Chem 36:188-197.

48. Sasidharan R, Manju SL, Uçar G, Baysal I, Mathew B (2016). Identification of Indole-Based Chalcones: Discovery of a Potent, Selective, and Reversible Class of MAO-B Inhibitors. Arch Pharm (Weinheim) 349:627-637.

49. Schrödinger Release 2020-4: Glide, Schrödinger, LLC, New York, NY, 2020.

50. Schrödinger Release 2020-4: LigPrep, Schrödinger, LLC, New York, NY, 2020.

51. Schrödinger Release 2020-4: Protein Preparation Wizard; Epik, Schrödinger, LLC, New York, NY, 2016; Impact, Schrödinger, LLC, New York, NY, 2016; Prime, Schrödinger, LLC, New York, NY, 2020.

52. Shalaby R, Petzer JP, Petzer A, Ashraf UM, Atari E, Alasmari F, Kumarasamy S, Sari Y, Khalil A. SAR and molecular mechanism studies of monoamine oxidase inhibition by selected chalcone analogs (2019). J Enzyme Inhib Med Chem 34:863-876.

53. Son SY, Ma J, Kondou Y, Yoshimura M, Yamashita E, Tsukihara T (2008). Structure of Human Monoamine Oxidase A at 2.2-A Resolution: The control of opening the entry for substrates/inhibitors. Proc Natl Acad Sci USA. 2008; 105: 5739-5744.

54. Tipton KF (2018). 90 years of monoamine oxidase: some progress and some confusion. J Neural Transm (Vienna) 125:1519-1551.

55. Tomar V, Bhattacharjee G, Kamaluddin, Kumar A (2007). Synthesis and antimicrobial evaluation of new chalcones containing piperazine or 2,5-dichlorothiophene moiety. Bioorg Med Chem Lett 17:5321-5324.

56. Van Bulck M, Sierra-Magro A, Alarcon-Gil J, Perez-Castillo A, Morales-Garcia JA (2019). Novel approaches for the treatment of Alzheimer's and Parkinson's disease. Int J Mol Sci 20:719.

57. Xiao G, Li Y, Qiang X, Xu R, Zheng Y, Cao Z, Luo L, Yang X, Sang Z, Su F, Deng Y (2017). Design, synthesis and biological evaluation of 4'-aminochalcone-rivastigmine hybrids as multifunctional agents for the treatment of Alzheimer's disease. Bioorg Med Chem 25:1030-1041.

58. Zhang P, Xu S, Zhu Z, Xu J (2019). Multi-target design strategies for the improved treatment of Alzheimer's disease. Eur J Med Chem 176:228-247.

59. Zhuang C, Zhang W, Sheng C, Zhang W, Xing C, Miao Z (2017). Chalcone: A Privileged Structure in Medicinal Chemistry. Chem Rev 117:7762-7810.

\section{Figures}


(A)

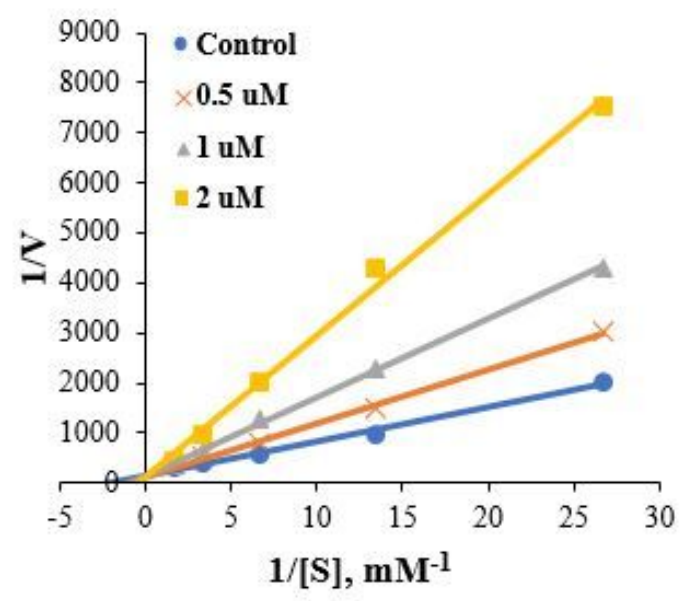

(c)

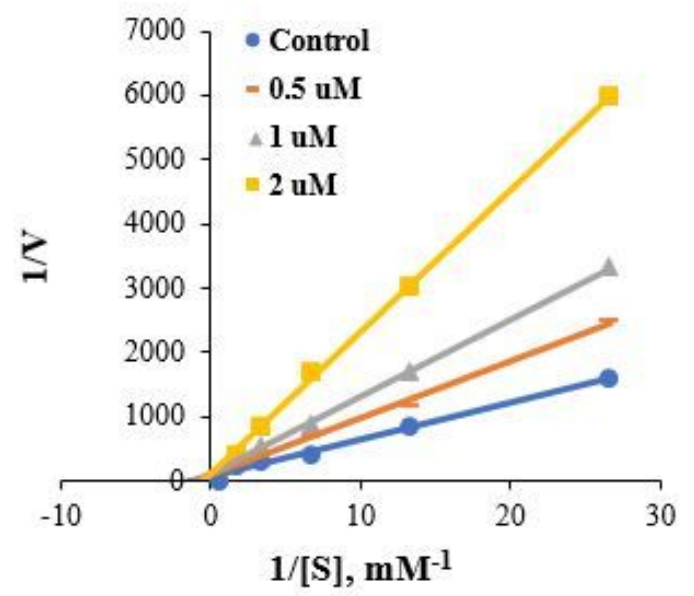

(B)

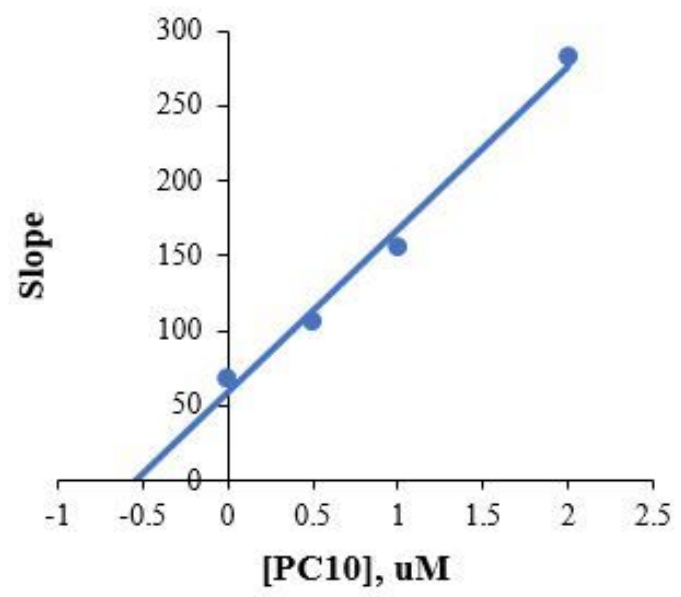

(D)

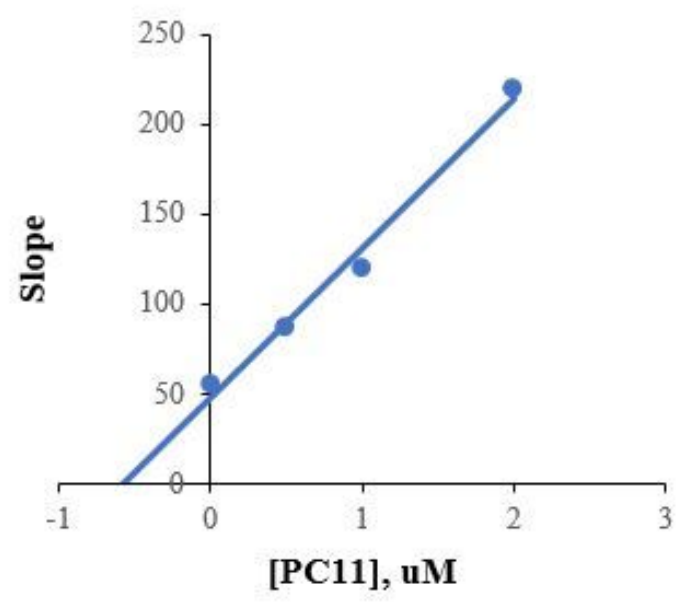

Figure 1

Lineweaver-Burk plots for MAO-B inhibition by PC10 (A) or PC11 (C), and respective secondary plots (B and D) of slopes vs. inhibitor concentrations. 


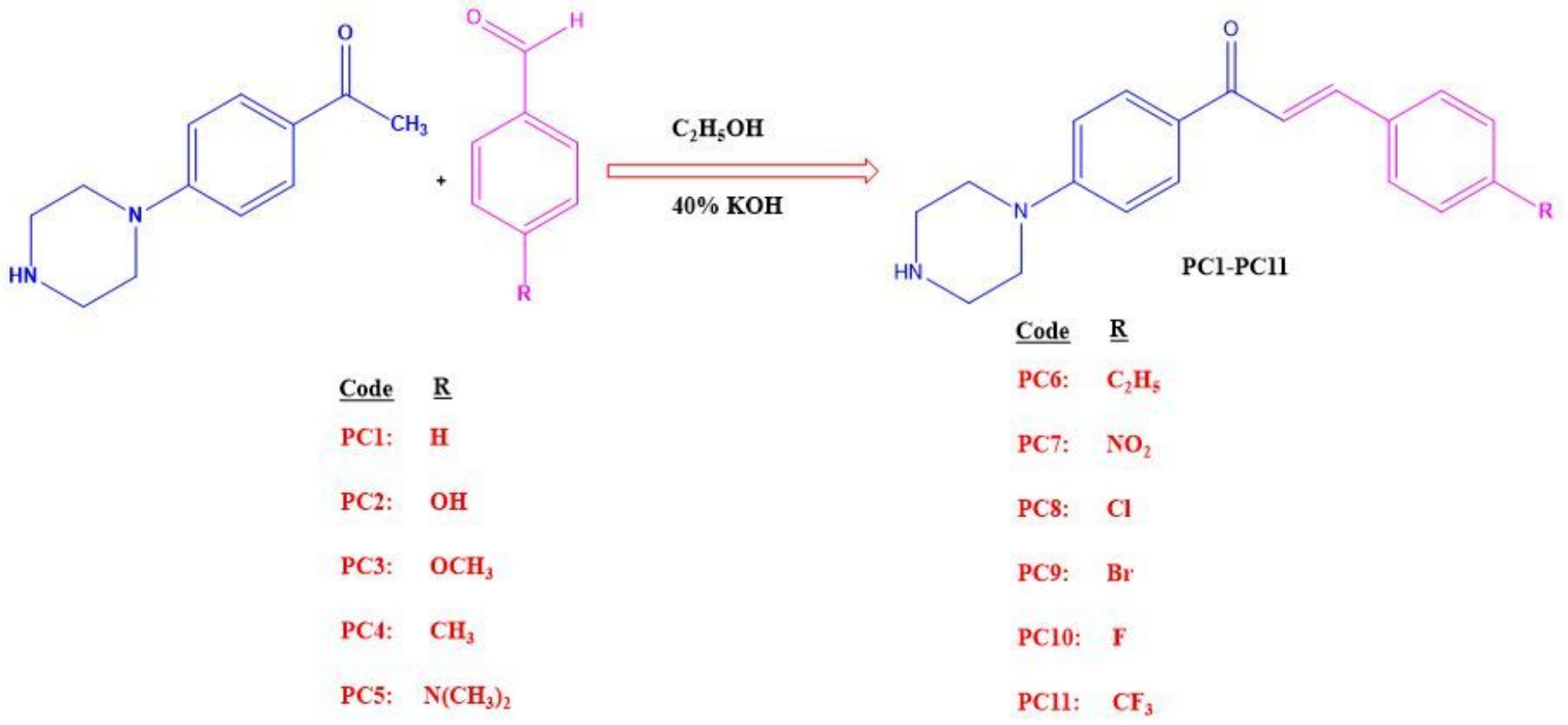

Figure 2

Schematic of the synthetic route used.

\section{Undialyzed Dialyzed}

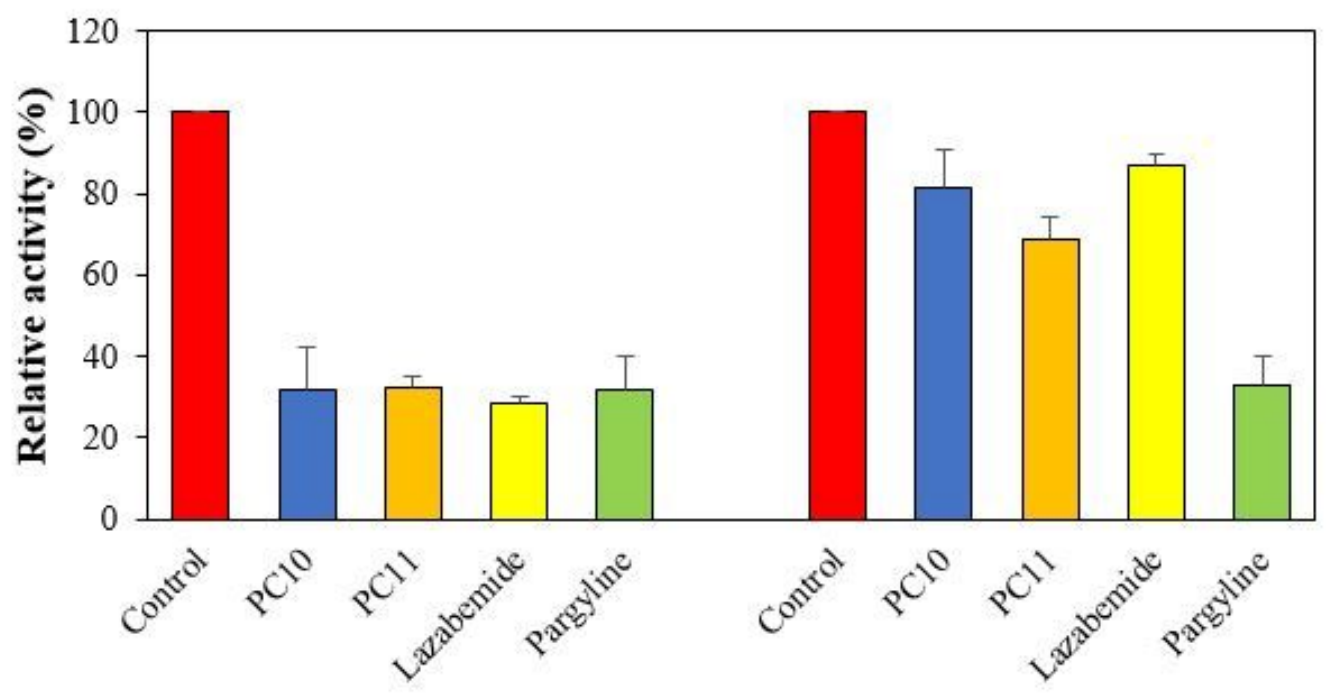

Figure 3

Recoveries of MAO-B inhibitions by PC10 and PC11 using dialysis experiments. 


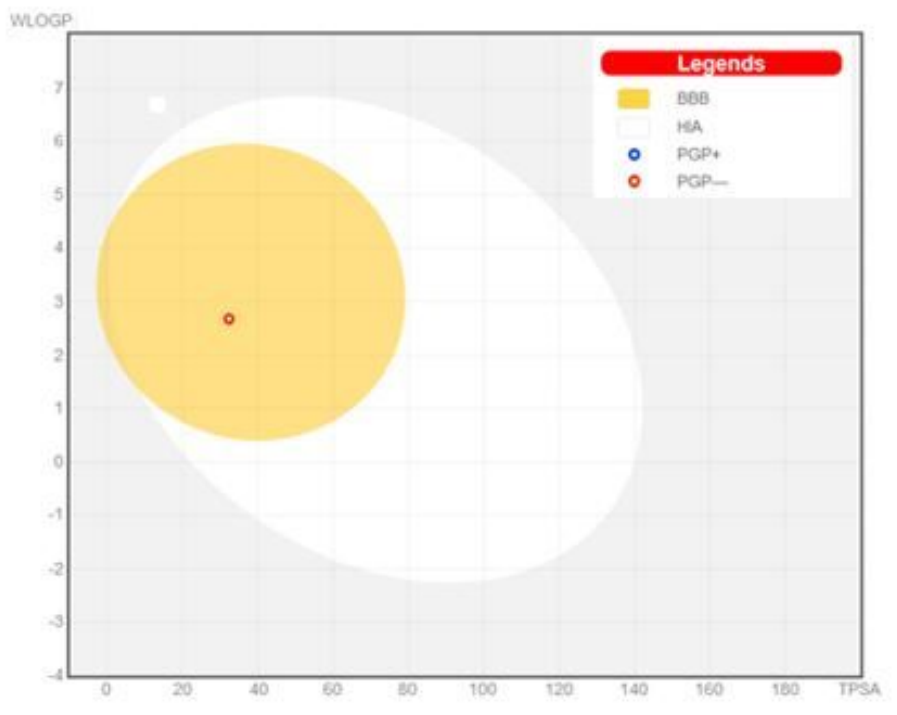

a

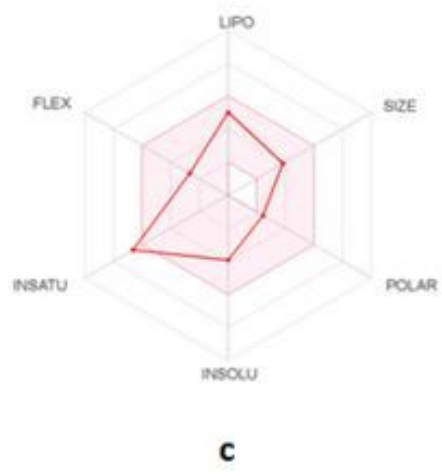

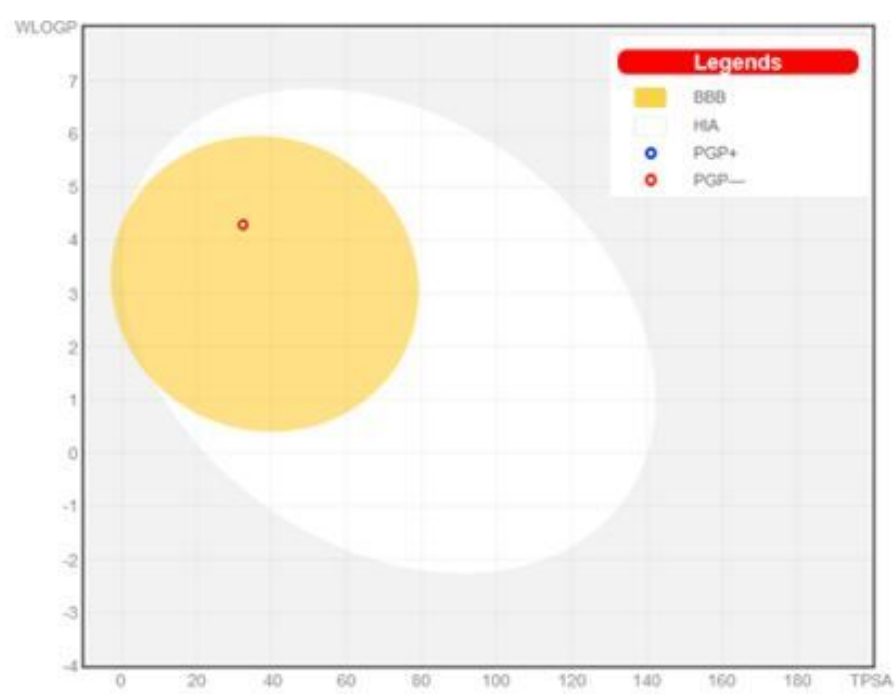

b

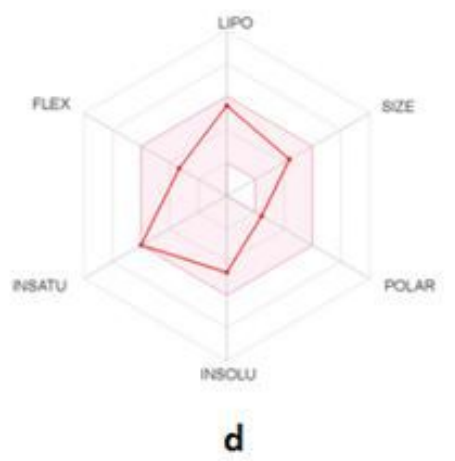

\section{Figure 4}

Representations of the boiled-egg graphs ( $a$ and b) and bioavailability radar plots (c and d) for PC10 and PC11 produced using the SwissADME web-tool. 
(A)

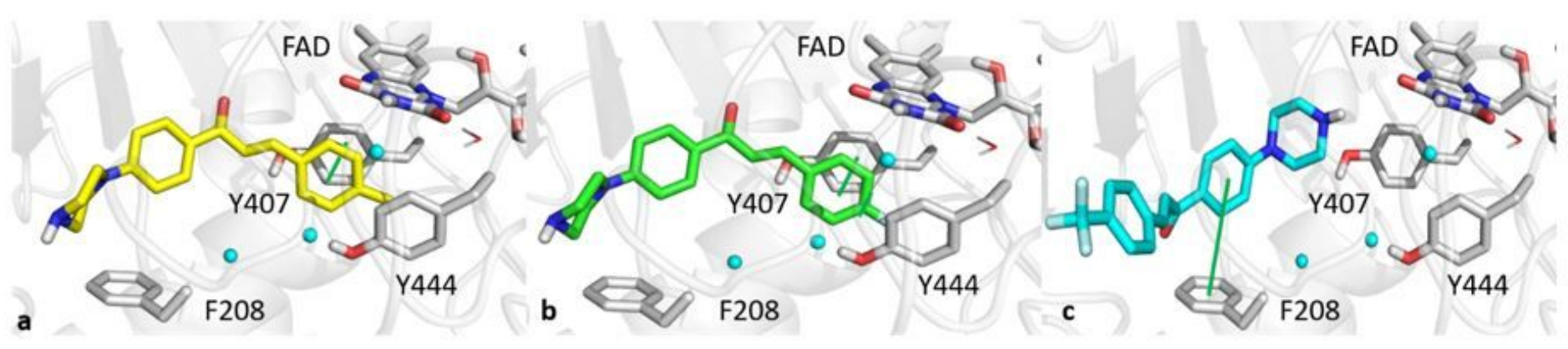

(B)

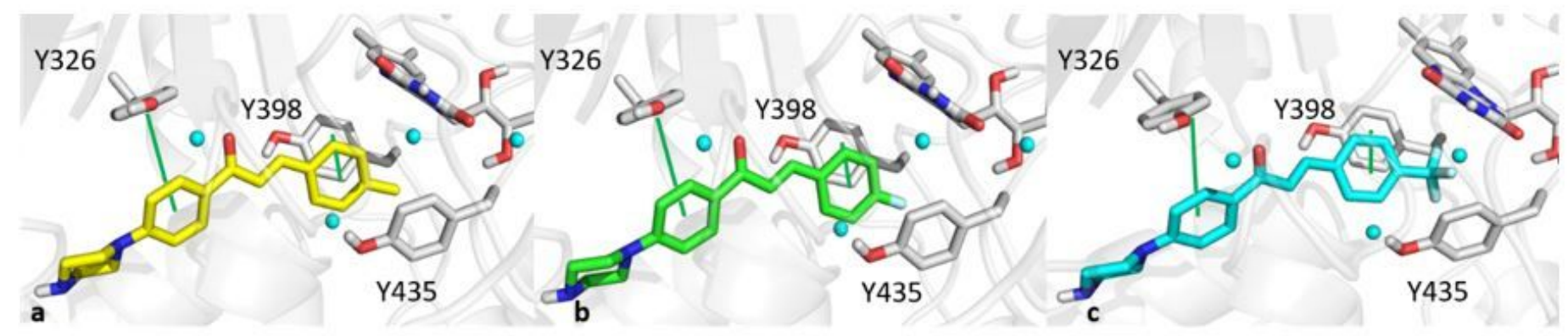

(C)

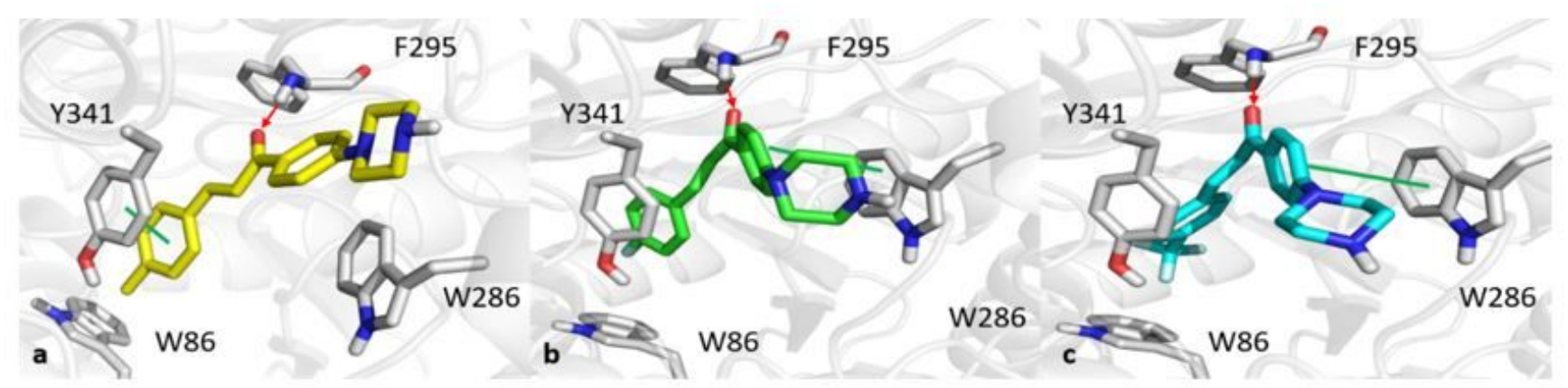

Figure 5

Molecular dockings with the binding pockets of MAO-A (A), MAO-B (B), or AChE (C) by PC4 (a, yellow sticks), PC10 (b, green sticks), or PC11 (c, cyan sticks), respectively. Green lines and red arrows indicate $\pi-\pi$ contacts and hydrogen bonds, respectively. Water molecules are depicted as cyan spheres. Docking score values for PC4, PC10, or PC11 with MAO-A were $-5.845,-5.730$, and $-4.811 \mathrm{kcal} / \mathrm{mol}$, respectively; with MAO-B were $-7.293,-7.285$, and $-7.113 \mathrm{kcal} / \mathrm{mol}$, respectively; and with AChE were $-6.099,-5.584$, and $-6.681 \mathrm{kcal} / \mathrm{mol}$, respectively. 


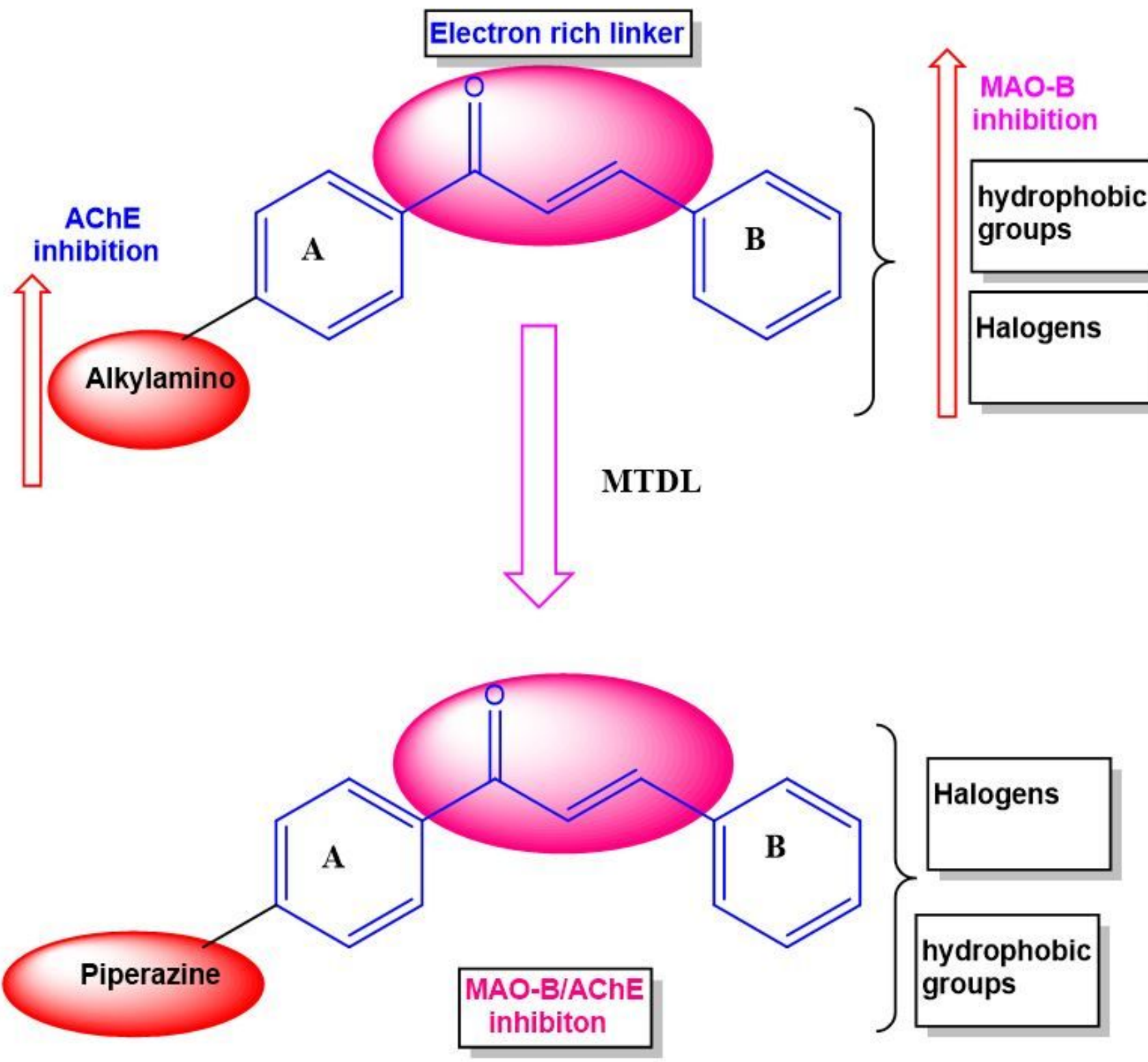

Figure 6

Design strategy used to produce piperazine-based multi-target directed ligands (MTDLs). 


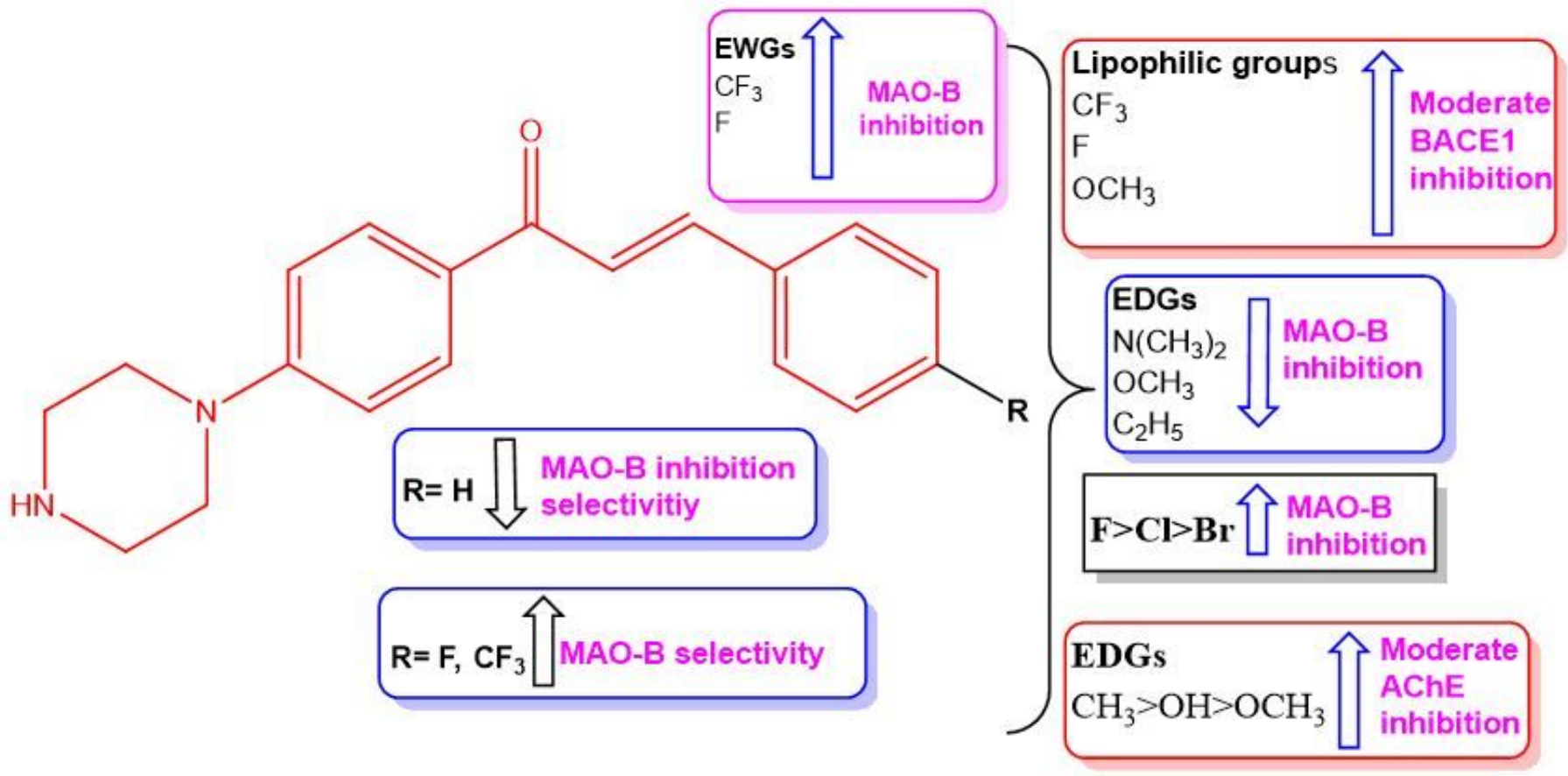

Figure 7

SARs analyses of the 11 piperazine-based chalcones produced. 